WSRC-STI-2006-00140 Rev. 1

Keywords: SNAP

9975 Packaging

Shipment

Corrosion

Internal

Stainless Steel

Hastelloy N

Retention: Permanent

\title{
MATERIALS COMPATIBILITY OF SNAP FUEL COMPONENTS DURING SHIPMENT IN 9975 PACKAGING
}

\author{
Philip R. Vormelker \\ Savannah River National Laboratory \\ Materials Science \& Technology Department \\ Publication Date: November 2006
}

\section{Washington Savannah River Company Savannah River Site Aiken, SC 29808}

This document was prepared in connection with work done under Contract No. DE-AC09-96SR18500 with the U. S. Department of Energy 


\section{DISCLAIMER}

This report was prepared as an account of work sponsored by an agency of the United States Government. Neither the United States Government nor any agency thereof, nor any of their employees, makes any warranty, express or implied, or assumes any legal liability or responsibility for the accuracy, completeness, or usefulness of any information, apparatus, product, or process disclosed, or represents that its use would not infringe privately owned rights. Reference herein to any specific commercial product, process, or service by trade name, trademark, manufacturer, or otherwise does not necessarily constitute or imply its endorsement, recommendation, or favoring by the United States Government or any agency thereof. The views and opinions of authors expressed herein do not necessarily state or reflect those of the United States Government or any agency thereof. 
DOCUMENT: WSRC-STI-2006-00140 Revision 1

TITLE: MATERIALS COMPATIBILITY OF SNAP FUEL COMPONENTS DURING SHIPMENT IN 9975 PACKAGING (U)

\section{APPROVALS}

Philip R. Vormelker, Author

Date:

Materials Application and Process Technology Group

MATERIALS SCIENCE \& TECHNOLOGY

J. I. Mickalonis, Technical Reviewer

Date:

MATERIALS SCIENCE \& TECHNOLOGY

R. L. Sindelar, Manager

Date:

Materials Application and Process Technology Group

MATERIALS SCIENCE \& TECHNOLOGY

N. C. Iyer, Manager

Date:

MATERIALS SCIENCE \& TECHNOLOGY

G. A. Abramczyk, Customer

Date:

Savannah River Packaging Technology

ENGINEERED EQUIPMENT AND SYSTEMS 
TABLE OF CONTENTS

Page

1.0 SUMMARY

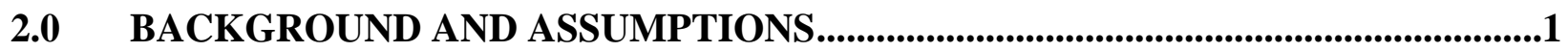

3.0 POTENTIAL FOR CORROSION/ DEGRADATION...................................................2

4.0 CONCLUSIONS .......................................................................................................4

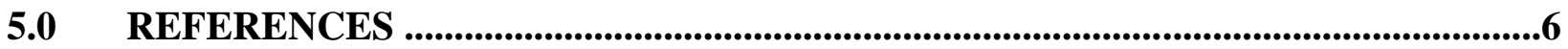

\section{LIST OF FIGURES}

Page

Figure 1. SNAP Fuel Convenience Can Packaging Configuration within the PCV (Primary Containment Vessel).(1) _.................................................................................................

Figure 2. Schematic of SNAP fuel rod originally designed for the SNAP 10FS-3 Reactor. (3)....9 Figure 3. Micrograph showing Hastelloy $\mathrm{N}$ base metal with chromized inner layer and the outer ceramic glass coating from early SNAP fuel development.(2).

Figure 4. Galvanic series of various alloys and metals in flowing seawater with arrows indicating alloys under evaluation (A, B, and $\mathrm{C}$ arrows). Note the $\mathrm{A}$ arrow indicates Alloy $\mathrm{C}$

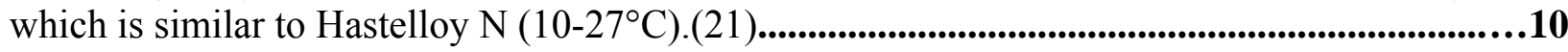

\section{LIST OF TABLES}

Table 1. Nominal Compositions (\%) for Hastelloy N, 304 Stainless Steel, and Aluminum Foil...7 Table 2. Physical Properties of Hastelloy N, 304 Stainless Steel, Aluminum Foil

\section{LIST OF ABBREVIATIONS}

LANL Los Alamos National Laboratory

NTS Nevada Test Site

PCV Primary Containment Vessel

PVC Polyvinylchloride

SARP Safety Analysis Report for Packaging

SNAP Systems for Nuclear Auxiliary Power

SRNL Savannah River National Laboratory

SRS Savannah River Site

SS Stainless Steel 


\subsection{SUMMARY}

Materials Science and Technology has evaluated materials compatibility for the SNAP (Systems for Nuclear Auxiliary Power) fuel for containment within a 9975 packaging assembly for a shipping period of one year. The evaluation included consideration for potential for water within the convenience can, corrosion from water, galvanic corrosion, tape degradation, and thermal expansion risk. Based on a review of existing literature and assumed conditions, corrosion and/or degradation of the 304 stainless steel (SS) Primary Containment Vessel (PCV) and the 304 stainless steel convenience cans containing the SNAP fuel is not significant to cause failure during the 1 year time shipping period in the 9975 packaging assembly. However, storage beyond the 1 year shipping period has not been validated.

\subsection{BACKGROUND AND ASSUMPTIONS}

SNAP fuel rods will be shipped in 9975 packaging from the Los Alamos National Laboratory (LANL) to the Nevada Test Site (NTS).(1) SNAP fuel was developed for compact, lightweight nuclear reactor heat sources that would provide long-term auxiliary power for spacecraft. Shipment and subsequent storage of the fuel beyond one year is not planned at this time and was not considered during this evaluation for materials compatibility.

A maximum of nine individual SNAP fuel rods will be contained within two 304 stainless steel convenience cans (Vollrath No. 88020) in a nesting pattern of eight rods (1.25 in OD) around the ID (approximately 4.625 in.) of a convenience can and one rod in the center, as represented in Figure 1. The second convenience can is used as a lid with the two convenience cans being taped together with PVC tape. The convenience cans with nine SNAP fuel rods will be placed into a 304 stainless steel primary containment vessel (PCV). The standard 9975 packaging assembly will contain the PCV.

The dimensions of individual SNAP fuel rods are 1.25 inches OD and 13.19 inches long per Figure 2. The minimum inside height of the combined Vollrath cans is 13.22 inches. This will be a snug fit for the 13.19 inch long fuel rods. If any swelling of the fuel has occurred, the fit may be even tighter. Aluminum foil packing will fill the vacant space to prevent fuel movement during shipment. Nominal compositions of the metal alloys (304 stainless steel, Hastelloy N, and aluminum) used in this package are shown in Table 1.

The SNAP fuel rods contain a solid homogeneous mixture of a fuel $\left({ }^{235} \mathrm{U}\right)$ and a moderator (hydrogen as $\mathrm{ZrH}_{\mathrm{x}}$ ), designated as $\mathrm{ZrUH}_{\mathrm{x}}$ or $\mathrm{UZrH}_{\mathrm{x}}$. A small amount of carbon (0.15 wt. \%) was added as a grain refiner to produce an optimum microstructure to increase yield strength during hydriding. The fuel element is clad with a Hastelloy $\mathrm{N}$ tube ( 0.015 in. wall thickness), a nickel alloy composition per Table 1. Surfaces of the cladding tube are chromized to provide enhanced adherence to a ceramic glass coating (Solarmaic, S14-35-SM2).(2) Chromizing (Solar Aircraft's F3-78 process) was performed on all tube surfaces to provide a diffusion barrier to the formation of molybdenum trioxide on the nickel alloy during fusing of the ceramic coating.(3-4) The chromium-rich surface enhances corrosion resistance, thermal stability, and wear-resistant properties. A metallographic cross-section of Hastelloy $\mathrm{N}$ with a chromized layer and subsequent coating from a developmental version of the cladding is shown in Figure 3 . The 
ceramic coating contains primarily oxides of aluminum, silicon, titanium, manganese, and barium with smaller amounts of sodium, lithium, and potassium.(4-5) This ceramic coating was generally applied in three firings $\left(\sim 1010{ }^{\circ} \mathrm{C}\right)$ during which a small quantity of samarium oxide $\left(\mathrm{Sm}_{2} \mathrm{O}_{3}\right)$ was included in the last two firings.(4-5) Depletion of the samarium oxide (a burnable poison) is intended to provide more than one year of stable reactor operation without complex mechanical control rods. The ceramic coating also acts as a barrier to hydrogen leakage from the fuel during irradiation. The fuel element was then backfilled with helium prior to final weld closure of a Hastelloy $\mathrm{N}$ end cap to individual tubes.

The SNAP fuel rods destined for this shipment were never installed in the SNAP 10FS-3 reactor for power generation and thus, the calculated decay heat is approximately 0.0023 Watts versus the 9975 SARP limit of 19 Watts (6). The temperature of the SNAP fuel is expected to be equilivalent to ambient conditions due to extremely low decay heat release. The fuel rods are expected to be dry and stable with no intentional moisture in the loaded convenience can except that from the loading environment at LANL.

\subsection{POTENTIAL FOR CORROSION/DEGRADATION}

Since there are three unique metals that will be contained within the SNAP convenience can, the potential for electrochemical interaction between these metals can be detrimental in the right environment. The actual fuel, $\mathrm{UZrH}_{\mathrm{x}}$, is protected by the chromized Hastelloy $\mathrm{N}$ tube and a ceramic coating and is expected to be stable at ambient conditions. The only plausible environment detrimental to the fuel is water, although it is not expected during final packaging of the fuel. The last material that could have possible interaction with the three metals is the PVC tape used to secure the two convenience cans together. The potential of each material's response in a water environment is considered by the following discussion.

\subsection{Stainless Steel}

The convenience can is constructed of 304 stainless steel which is expected to be resistant to corrosion in freshwater or condensation as long as chloride levels are below $250 \mathrm{ppm} .(7)$

\subsection{Hastelloy N With Chromized Diffusion Coating}

The outside cladding on the fuel is Hastelloy N, an alloy that was originally developed by the Oak Ridge National Laboratory as a container material for high temperature $\left(>700{ }^{\circ} \mathrm{C}\right)$ molten fluoride salts. The SNAP fuel was designed to be used in a liquid sodium-potassium eutectic alloy at $650{ }^{\circ} \mathrm{C}$ with a lifetime of greater than one year. The chromized surface layer on the Hastelloy $\mathrm{N}$ material was used to improve its resistance to internal oxidation due to the high fusing temperatures of the ceramic coating. Hastelloy $\mathrm{N}$ (without the high chromium surface content) is similar to Hastelloy C-276 and C-22 in corrosion and high temperature oxidation resistance.(8)

The corrosion rate in seawater for Hastelloy $\mathrm{N}$ was measured as 0.0001 mil per year.(9) This corrosion rate is extremely low and should be further reduced with additional chrome content on the surface. Low corrosion rates in seawater with significant chloride content is a positive 
indication that Hastelloy N's corrosion resistance to water would be very high. Thus, the fuel cladding is expected to be very resistant to corrosion to any water/condensate in the convenience can.

\subsection{Aluminum Foil}

The current alloy used for Reynolds Wrap ${ }^{\circledR}$ aluminum foil is 8111 (10) which is similar in composition to the 1145 alloy but slightly different than the others shown in Table 1. In general, these aluminum alloys are resistant to corrosion in water with $\mathrm{pH}$ levels of 6-9, conductivity levels below $10 \mu \mathrm{S} / \mathrm{cm}$, and with no halide ions.(11-13) Aluminum forms a protective airformed oxide which should protect itself for the 1 year shipping period.

Even though aluminum foil has the lowest melting point of the three metals used in the 9975 per Table 2, the highest internal temperature expected during a fire condition is $525^{\circ} \mathrm{C}$ per the 9975 SARP.(6) Therefore, the aluminum foil will not melt during a fire condition. Aluminum's higher thermal conductivity should not be a concern due to the low heat release of the SNAP fuel.

\subsection{Galvanic Corrosion}

While each of the above mentioned alloys is individually resistant to corrosion in water to varying degrees; a potential for galvanic corrosion exists when they are in contact with each other in the convenience can with some water content. According to the galvanic series in Figure 4, aluminum alloys are the least noble of the alloys in contact with each other in the convenience can. This means that in the presence of seawater, corrosion of aluminum foil will probably occur. This will also occur in tap water. Since the fuel rods will be in point contact with the convenience can, crevice corrosion may occur on the stainless steel can (assuming water is present) at the point of contact. The surface area of the fuel is expected to be greater than that of the can, thus increasing the potential for galvanic corrosion of the can in the presence of water. Since water is precluded in the convenience can and containment vessel, galvanic and crevice corrosion is not expected to occur.

\subsection{PVC Tape}

PVC (polyvinylchloride) tape is used to secure the two convenience cans together to confine the SNAP fuel rods. At ambient temperatures the PVC tape is expected to remain in good condition without interaction with the fuel or the convenience can. However, during previous elevated temperature testing of 12 mil PVC film, charring and significant outgassing was experienced at $121^{\circ} \mathrm{C}\left(249^{\circ} \mathrm{F}\right) .(14)$ Products of outgassing include chlorides, since significant levels are part of the monomer used to produce PVC. Also, stress corrosion cracking was observed underneath PVC pipe labels on 304 stainless steel cooling water piping in SRS reactors due to leaching of chlorides from the label. Since temperatures above ambient are not expected in the convenience can, tape outgassing is not expected. However, there is also a risk of stress corrosion cracking on convenience can surfaces below the PVC tape if left on for long periods.(15) The use of nonchloride based tape is suggested. However, corrosion of the convenience can does not compromise the structural integrity of the stainless steel Primary Containment Vessel. 


\subsection{Potential for Water in the Convenience Can}

If SNAP fuel is loaded into the convenience can in an exterior or non-air conditioned environment (temperature $=27^{\circ} \mathrm{C}, 50 \% \mathrm{RH}, 15^{\circ} \mathrm{C}$ dew point $*$ ), the air inside the can will contain saturated moisture with a density of $12.83 \mathrm{~g} / \mathrm{m}^{3}$.(16) When the outer shell is cooled to it's dew point temperature at some point during shipping, the saturated air inside the convenience can (assume air tight) may condense. The amount of free space inside the double convenience can is estimated to be $34 \%$ without consideration for the aluminum foil volume. Using a value of $222 \mathrm{in}^{3}$ for the interior volume of the two convenience cans and multiplied by $34 \%$ to represent the unused volume of $75.5 \mathrm{in}^{3}$, The amount of condensed moisture can be found by multiplying saturated moisture density $\left(12.83 \mathrm{~g} / \mathrm{m}^{3}\right)$ by $75.5 \mathrm{in}^{3}\left(1.23 \times 10^{-3} \mathrm{~m}^{3}\right)$ to obtain a value of 0.016 grams of water.

When Rice (17) used pure nickel foil exposed to various humidity levels, moisture was absorbed on the nickel surface and oxidation occurred. At the 30\% RH level, nickel oxidizes and gains weight at $0.011 \mu \mathrm{g} / \mathrm{cm}^{2} \mathrm{hr}$. Assuming the following reaction (1) with $30 \% \mathrm{RH}$ air:

$$
\text { (1) } \mathrm{Ni}+\mathrm{H}_{2} \mathrm{O} \leftrightarrow \mathrm{NiO}+\mathrm{H}_{2}
$$

For each mole of water, one mole of $\mathrm{NiO}$ is formed. Using $1 \mathrm{~cm}^{2}$ surface area and a time of one hour, $1.1 \mathrm{e}^{-8} \mathrm{~g}$ of NiO is created. One SNAP fuel rod has a calculated surface area of $51.3 \mathrm{in}^{2}$ $\left(331 \mathrm{~cm}^{2}\right)$. Using 8760 hours $/ \mathrm{yr}$. and the oxidation rate of $0.011 \mu \mathrm{g} / \mathrm{cm}^{2} \mathrm{hr}$, the amount of $\mathrm{NiO}$ is calculated at 0.032 grams of NiO. This amounts to $4.3 \mathrm{e}^{-2} \%$ moles of NiO. This is a very small amount considering this value is for pure nickel. Chromized Hastelloy $\mathrm{N}$ is expected to oxidize at an even lower rate, if at all in a low moisture environment. Thus, any water within the convenience can from condensation is not considered a corrosion risk for the Hastelloy $\mathrm{N}$ fuel rods, 304 stainless steel convenience can, and aluminum foil filler material for the one year shipping period.

\subsection{Thermal Expansion Risk}

Since there is a tight fit, height wise, between the $13.19 \mathrm{in}$. tall fuel rods and the inside height of the double convenience can (13.22 in.), the risk of thermal expansion should be considered. Since the thermal expansion coefficient of 304 stainless steel is approximately $50 \%$ greater than that of Hastelloy $\mathrm{N}$ per Table 2, the convenience can is expected to grow more than the SNAP fuel should temperatures exceed ambient conditions. Thermal expansion measurements for alpha uranium (18) and zirconium hydrides (19) in Table 2 are below that for Hastelloy $\mathrm{N}$ except for the highest value for alpha uranium. The thermal expansion values for alpha uranium were based on varying fabrication techniques and may not represent the correct values for SNAP fuel elements. Thus, interference conditions are not expected based on original dimensions. However, the actual fuel rod dimensions should be measured to confirm if any changes have occurred during storage since their original fabrication date.

\subsection{CONCLUSIONS}

Various scenarios were reviewed for potential instances of corrosion and degradation. In order for corrosion to occur, water must be present. Although water is not specifically mentioned in

* Weather conditions Albuquerque area, August 31, 2006, National Weather Service 
the justification for SNAP fuel content in 9975 packaging (1), it is expected that the fuel will be dry. The only possible moisture in the fuel containing convenience can will be that from the moisture level in the environment of the loading area at LANL. Other degradation scenarios are not expected. Integrity of the PCV is maintained even if the convenience can is compromised. Even if there were a breach in the fuel cladding, there would be no effect on safety performance of the PCV. Current SNAP fuel rod dimensions should be confirmed or fit tested in the convenience can. Materials Science \& Technology concludes that there are sufficient data to establish the technical basis for safe shipping of SNAP fuel rods at the referenced conditions in the Model 9975 Shipping Package for up to a one year shipping period. 


\subsection{REFERENCES}

1. "Justification for Shipment of Systems for Nuclear Auxiliary Power (SNAP) Fuel Content in the 9975 Packaging," S-TRT-G-00001, Revision 0, September 2006.

2. J. G. Asquith, SNAP Reactor Programs Progress Report May-July 1968, AI-AEC-12729, Atomics International, Canoga Park, CA, September 15, 1968.

3. R. E. Lords, SNAP and AI Fuel Summary Report, WINCO-1222, August 1994.

4. G. F. Burdi (ed.), SNAP Technology Handbook, Volume II, Hydride Fuels and Claddings, NAA-SR-8617-V2, Atomics International, Canoga Park, CA, November 15, 1964

5. D. W. Knef et al, A Document Review to Characterize Atomic International SNAP Fuels Shipped to INEL 1966-1973, INEL-95/0131, September 1995.

6. "Model 9975 B(M)F-85 Safety Analysis Report for Packaging," WSRC-SA-2002-00008, Revision 0, December 2002.

7. WSRC ENGINEERING STANDARD WSRC-TM-95-1, STANDARD No. 05952 Revision 4, "Required Practices to Minimize Chloride Induced Stress Corrosion Cracking of Austenitic Stainless Steel," May 30, 2006.

8. Hastelloy® Alloy N Technical Information, H-2052A, Haynes International, Inc., 1992

9. Kubose, D. A. et al, "Measurement of Seawater Corrosion of SNAP Container Alloys Using Radioactive Tracer Techniques," USNRDL-TR-1092, January 1, 1966.

10. http://www.alcoa.com/reynoldskitchens/en/product info page.asp?info page id=743\&prod $\mathrm{id}=1789 /$.

11. D. W. Sawyer and R. H. Brown, "Resistance of Aluminum Alloys in Fresh Waters," Corrosion, Vol. 3 (No. 9), 1947, p 443..

12. H. P. Godard, "The Corrosion Behavior of Aluminum in Natural Waters," Can. J. Chem. Eng., Vol 38, 1960, p 167.

13. W. H. Ailor, Jr., "A Review of Aluminum Corrosion in Tap Water, J. Hydronautics, Vol. 3 (No. 3)1969, p 105.

14. P. R. Vormelker, "Polymer Outgassing Tests for Shipping Packages 9965-9975 (U), SRTMTS-955033, September 1, 1995.

15. W. C. Rion, "Stainless Steel Information Manual For The Savannah River Plant", DPE2140, Engineering Department, E.I. DuPont De Nemours, Wilmington, DE, (1960).

16. http://hyperphysics.phy-astr.gsu.edu/hbase/kinetic/watvap.html

17. D.W. Rice, P. B. P. Phipps, and R. Tremoureux, Atmospheric Corrosion of Nickel, J. Electrochem Soc., Vol. 127, No. 3, pp 563-568, March 1980.

18. C. R. Tipton (ed.), Reactor Handbook Volume 1 Materials, $2^{\text {nd }}$ Edition, Interscience Publishers, New York, 1960, pp 118-119.

19. R. L. Best, "Thermophysical Properties of Zirconium Hydride," Transactions ASM, Vol. 55, 1962, p 562

20. D. Benjamin (Ed.), Metals Handbook Ninth Edition Volume 3 Properties and Selection: Stainless Steel, Tool Materials and Special-Purpose Metals, ASM (1960), pp 34-35.

21. http://www.corrosionsource.com/handbook/galv_series.htm 
Table 1. Nominal Compositions (\%) for Hastelloy N, 304 Stainless Steel, and Aluminum Foil

\begin{tabular}{|c|c|c|c|c|c|c|c|c|}
\hline Alloy & Nickel & Chromium & Molybdenum & Iron & Silicon & Manganese & Carbon & Others \\
\hline Hast. N & 71 & 7 & 16 & $8.0^{*}$ & $1 *$ & $0.80^{*}$ & $0.08 *$ & $\begin{array}{l}\mathrm{Co}=0.20^{*} \\
\mathrm{Cu}=0.35^{*} \\
\mathrm{~W}=0.50 * \\
\mathrm{Al}+\mathrm{Ti}=0.35^{*}\end{array}$ \\
\hline 304 & $8-10.5$ & $18-20$ & & Bal. & $1 *$ & 2.0 & $0.08 *$ & \\
\hline Al 1145 & & & & & $0.55^{* *}$ & & & Al $99.45 \mathrm{~min}$ \\
\hline Al 2024 & & & & $0.5^{*}$ & $0.05^{*}$ & $0.9^{*}$ & & $\begin{array}{l}\mathrm{Mg}=1.8^{*} \\
\mathrm{Cu}=4.9^{*} \\
\mathrm{Zn}=0.25^{*} \\
\text { Bal. Al }\end{array}$ \\
\hline Al 3003 & & & & $0.7^{*}$ & $0.6^{*}$ & $1.5^{*}$ & & $\begin{array}{l}\mathrm{Cu}=0.2^{*} \\
\text { Bal. Al }\end{array}$ \\
\hline Al 5052 & & $0.35 *$ & & $0.4^{*}$ & $0.25 *$ & $0.1 *$ & & $\begin{array}{l}\mathrm{Mg}=2.8^{*} \\
\text { Bal. Al }\end{array}$ \\
\hline Al 5056 & & $0.35^{*}$ & & $0.4^{*}$ & $0.3 *$ & $0.2^{*}$ & & $\mathrm{Mg}=5.6^{*}$ \\
\hline Al 8111 & & & & $1.1^{*}$ & $1.0 *$ & & & Bal.Al \\
\hline
\end{tabular}

*Maximum

** $\mathrm{Si}+\mathrm{Fe}$ Maximum

Table 2. Physical Properties of Hastelloy N, 304 Stainless Steel, Aluminum Foil, Alpha Uranium, and Zirconium Hydrides $(8,10,19,20)$

\begin{tabular}{|c|c|c|c|}
\hline & $\begin{array}{l}\text { Melting } \\
\text { Range, }{ }^{\circ} \mathrm{C}\end{array}$ & $\begin{array}{l}\text { Mean Coeff. } \\
\text { Thermal Exp. } \\
\left(21-204^{\circ} \mathrm{C}\right)\end{array}$ & $\begin{array}{l}\text { Thermal } \\
\text { Conductivity } \\
\left(100^{\circ} \mathrm{C}\right)\end{array}$ \\
\hline Hast. $\mathbf{N}$ & $1300-1400$ & $11.6 \times 10^{-6} /{ }^{\circ} \mathrm{C}$ & $11.5 \mathrm{~W} / \mathrm{m}-\mathrm{K}$ \\
\hline 304 SS & 1371-1399 & $17.3 \times 10^{-6} /{ }^{\circ} \mathrm{C}$ & $16.2 \mathrm{~W} / \mathrm{m}-\mathrm{K}$ \\
\hline $\begin{array}{l}\text { Al Foil } \\
\text { Alloys }\end{array}$ & $643-657$ & ${ }^{1} 23.6 \times 10^{-6} /{ }^{\circ} \mathrm{C}$ & ${ }^{2} 222 \mathrm{~W} / \mathrm{m}-\mathrm{K}$ \\
\hline a Uranium & stable to 400 & ${ }^{3} 9-16 \times 10^{-6} /{ }^{\circ} \mathrm{C}$ & - \\
\hline $\mathrm{ZrH}_{\mathbf{x}}$ & $\begin{array}{l}\text { (U melts } 1130) \\
\text { stable to } 300 \\
\text { (Zr melts } 1830)\end{array}$ & ${ }^{4} 7.4 \times 10^{-6} /{ }^{\circ} \mathrm{C}$ & - \\
\hline
\end{tabular}



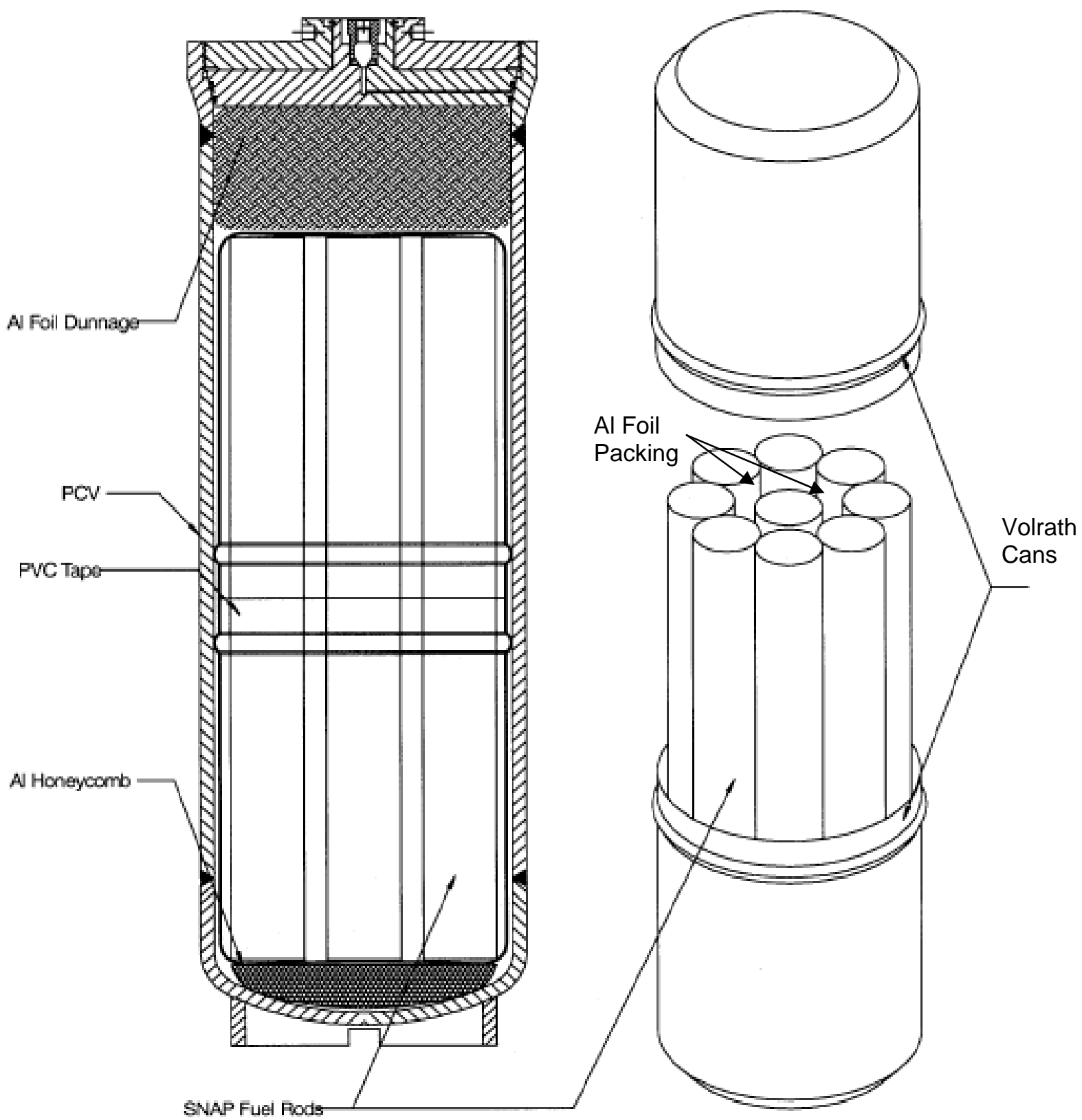

Figure 1. SNAP Fuel Convenience Can Packaging Configuration within the PCV (Primary Containment Vessel).(1) Aluminum foil will be added to the space between the fuel rods to prevent fuel movement. 


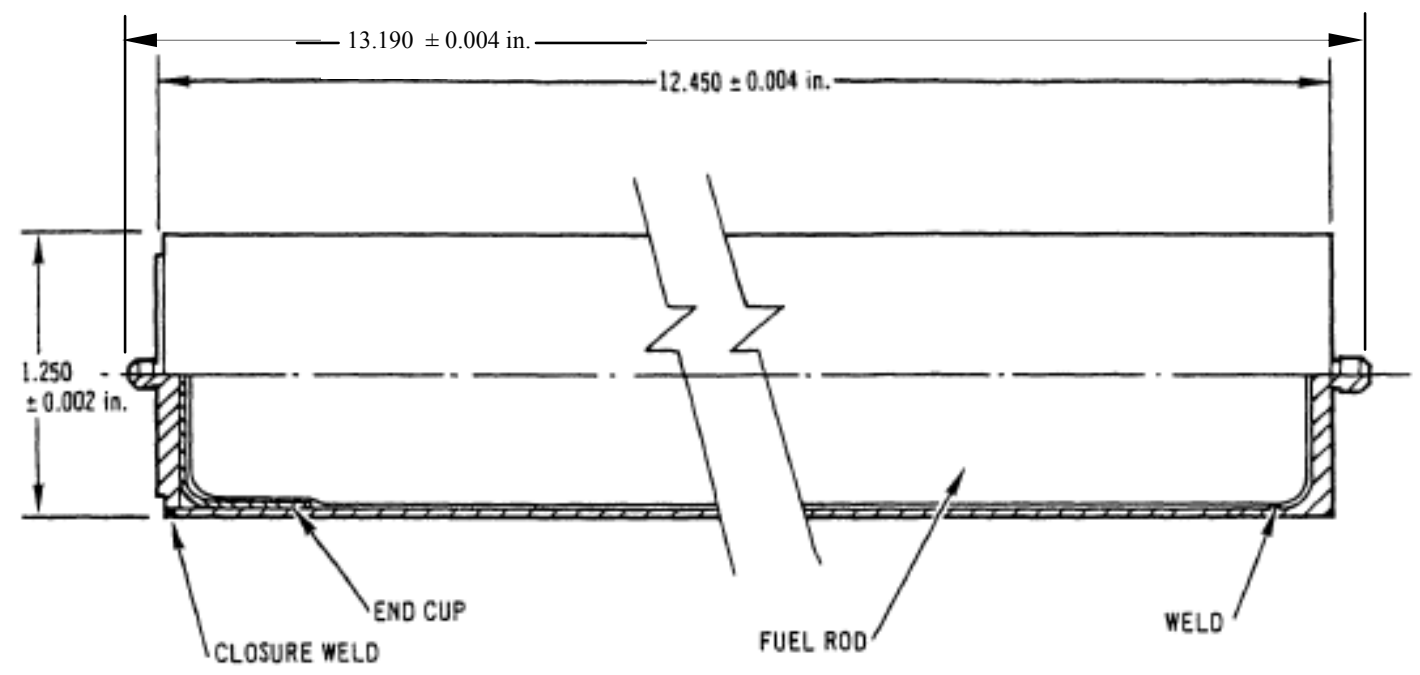

Figure 2. Schematic of SNAP fuel rod originally designed for the SNAP 10FS-3 Reactor. (3)

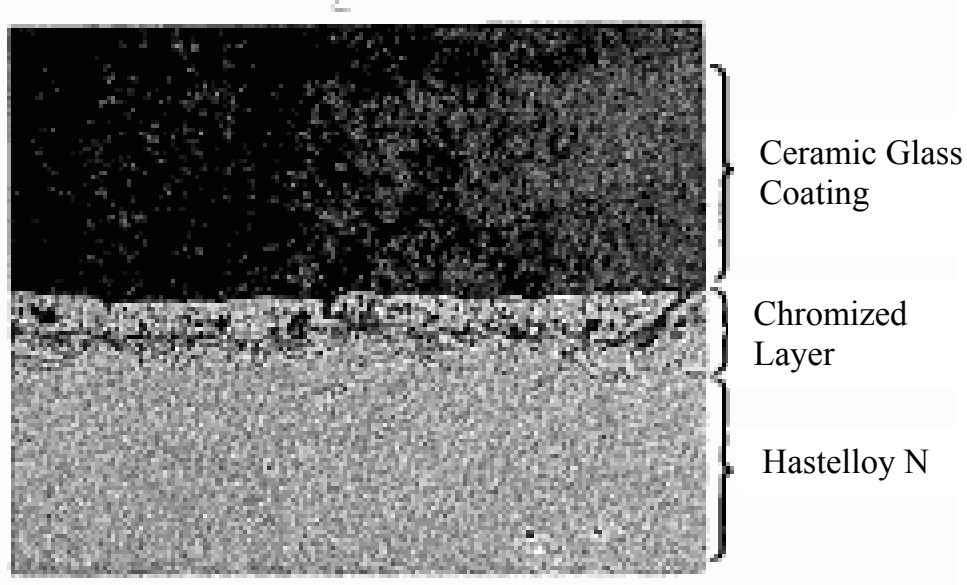

Figure 3. Micrograph showing Hastelloy $\mathrm{N}$ base metal with chromized inner layer and the outer ceramic glass coating from early SNAP fuel development.(2) 


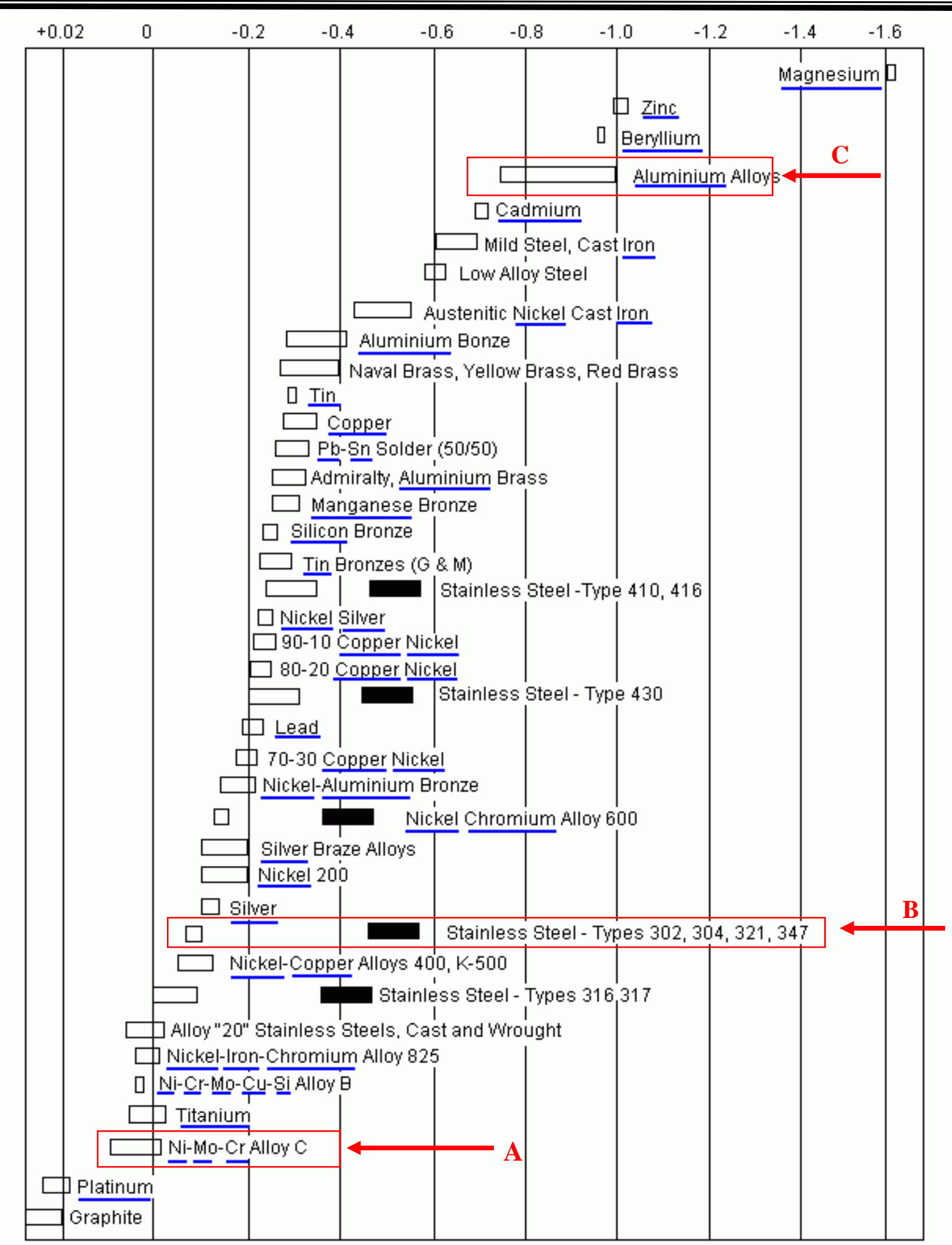

Figure 4. Galvanic series of various alloys and metals in flowing seawater with arrows indicating alloys under evaluation (A, B, and $\mathrm{C}$ arrows). Note the $\mathrm{A}$ arrow indicates Alloy $\mathrm{C}$ which is similar to Hastelloy $\mathrm{N}\left(10-27^{\circ} \mathrm{C}\right) .(21)$ 


\section{Distribution}

J. S. Bellamy, 773-41A

P. S. Blanton, 773-41A

G. A. Abramczyk, 773-41A

N. C. Iyer, 773-41A

R. L. Sindelar, 773-41A

J. I. Mickalonis, 773-41A

P. R. Vormelker, 773-41A 